\title{
French Policy in the Sphere of Tourism
}

\author{
Ekaterina Vladislavovna Kolupaeva ${ }^{1} \&$ Liliya Rifhatovna Galimzyanova ${ }^{1}$ \\ ${ }^{1}$ Kazan Federal University, Russia \\ Correspondence: Ekaterina Vladislavovna Kolupaeva, Kazan Federal University, Russia. E-mail: \\ kolupaeva1995@gmail.com
}

Received: June 9, 2019

doi:10.5539/jpl.v12n5p71
Accepted: August 25, $2019 \quad$ Online Published: August 31, 2019

URL: https://doi.org/10.5539/jpl.v12n5p71

\begin{abstract}
In this paper we present the current situation of France in the field of tourism and describe the main state organizations that carry on business in the sphere of tourism development in the French Republic. We also give examples of the main events delivered by these institutions for the sustainable development of the tourism industry in France. Today in France there are several state structural units that are full of vitality in this direction. Of these, the following departments and organizations were considered: Ministry of Foreign Affairs and International Development; Ministry of Commerce and Finance; Interagency Committee on Tourism, Tourism Promotion Council, Atout France, etc.

Thanks to the active work carried out at the state level, France today holds one of the leading positions among the countries to be most frequently visited by tourists. Moreover, the results of this smart policy are the annual income from the development of the tourism industry in France, which, in turn, significantly affects the economic welfare of the country.

Thus, a carefully thought-out state policy in the field of tourism has a favorable effect on the socio-economic condition of the country as a whole.
\end{abstract}

Keywords: tourism, France, state tourism policy, tourism in France, state institutions in the field of tourism

\section{Introduction}

Tourism is one of the most important economic sectors in France. The sector provides jobs for more than a million people, and the events hosted in this area attract more than 300 million people annually. France ranks first in the world in the number of tourists -81 million. In 2018, the share of the tourism industry in GDP of the country was $9.5 \%$. And, in connection with the presented indicators, it becomes clear that tourism as the social and economic sphere of public life is developing not only at the account of various private organizations. For sustainable development and functioning of Tourism in France, a clearly defined framework of state institutions of power has been created. This article provides a description of the main ones, as well as the examples of some of the activities they sponsor to develop tourism in the country and outside its national territory.

\section{2. methods}

Within the study, analytical, statistical and comparative methods were applied.

\section{3. results and discussion}

It is known that there is no institutional unit of the Ministry of Tourism at the managerial level in France. The tourism management mechanism in France is documented in the national Tourism Code.

Thus, the activities in the field of international tourism are performed by such institutions as the National Tourism Board - the main advisory body that deals with the main directions of development for national and international tourism; Ministry of Foreign Affairs and International Development; Ministry of Commerce and Finance; Interdepartmental Committee on Tourism, created to promote the French tourism brand abroad. The National Federation of Tourism Offices, as well as the Tourism Promotion Council also engage in these activities at the federal level. Since 2014, the country's tourism sector has been supervised by the Ministry of Foreign Affairs, which reports to Atout France - the Agency for Tourism Development of France, the main tasks of which are to develop inbound tourism (where the embassies of the French Republic play an important role), as well as to regulate domestic tourism (incl. the process of licensing tour operators and hotel certification). Today Atout France is a joint tourism development company in France. It brings together the experts in the field of tourism, as 
well as the representatives of various state and non-governmental organizations that are involved in promoting the French tourism product in the world market. As part of the organization's activities, about 2000 events are held each year to promote France as a tourist destination: various advertising campaigns, press tours for media representatives and exhibitions for professionals in the field of international tourism are among them. In addition, it is worth giving prominence to the World Tourism Organization in shaping the policy of France in the sphere of international tourism with which the country coordinates its activities within international tourism law.

First of all, let us consider the National Council on Tourism which is a central element in the tourism management system in France. The history of this institution has more than a hundred years - the National Council was founded in 1910. The Council performs deliberative and supervisory functions. It participates in the development of the state strategy, discussion of projects, legislative documents and other issues related to the field of tourism. The National Council brings together various representatives of the tourism sector to exchange views. The National Council consists of 200 members appointed for a five-year period, and the Minister of Tourism is its president.

In the field of international tourism, the National Council deals with the state programs for its development, and also publishes editions concerning marketing research in this area. In addition, the National Council includes a department for European and international affairs, engaged in expert activities. Within foreign cultural policy, the National Council investigates the possibilities of disseminating French culture through tourism activities. The result of this activity are publications that consider the interaction of international tourism with other areas of foreign cultural policy. As an example, we can mention the Report of the European and International Affairs Department, dedicated to the organization of cultural and sports events in the context of tourism development.

The Ministry of Foreign Affairs and International Development also deals with France's foreign affairs in tourism. Its domain of competence includes promoting France as a tourist destination through cooperation with non-governmental French organizations in the field of tourism (for example, with Atout France), working out state plans and strategies for the development of international tourism. In its activities, the Ministry of Foreign Affaires relies on the existing cultural and diplomatic network abroad. On the website of the French Ministry of Foreign Affairs, a separate section is dedicated to tourism development in the context of foreign policy, which details the current state of the tourism sector in France, government-sponsored events, and the functions of the Ministry of Foreign Affairs in this area. Thus, international tourism is an important area of activity of the MFA, the main task of which is to strengthen the attractiveness of the image of France and to extend its cultural influence in the world. One should not forget about the economic importance of tourism, contributing to the growth of the French economy.

The Ministry of Trade and Finance operates in the field of international tourism through the Directorate-General for Entrepreneurship (La Direction Générale des Entreprises, DGE), established in 2014 instead of the Directorate-General for Competitiveness, Industry and Services, which existed earlier. Its structure includes a service for tourism, trade, crafts and services (Service du tourisme, du commerce, de l'artisanat et des services, STCAS). This body deals with the development of both domestic and international tourism. Within foreign cultural policy, the tourism service organizes various international events in the field of tourism, where participating countries, including France, can present their projects aimed at promoting tourism and share their experience in this area. An example of such an event is the International Tourism Exhibition, one of the key events in the tourism sector. In 2017, the exhibition was held in Paris from March 16 to March 19.

The Interdepartmental Committee on Tourism was founded in 2004 to work out the strategies for the development of international tourism. The committee organizes meetings several times a year under the leadership of the Prime Minister of France. The last meeting was held in November 2016, during which the items of the agenda were ensuring the safety of tourists, increasing the competitiveness of French tourism in the world market. The work of the committee has resulted in an outcome document that sets the French government the task of increasing the number of foreign tourists arriving to 100 million by 2020 . To achieve this goal, several measures are proposed, among which - the development of cultural tourism by attracting the interest of foreign tourists to cultural heritage sites located in the regions of France. Thus, the Interagency Committee is involved in the development of tourism as a direction of foreign cultural policy, contributing to the spread of French culture.

Among the main strategies developed by the Ministry of Foreign Affairs and Development of France, one can distinguish "30 specific solutions for French international tourism as a world leader". The document was created in 2014 and submitted by Foreign Minister Laurent Fabius. First of all, this strategy draws attention to the exclusive role of tourism in the structure of the French economy. According to the document, France's position as a world leader in the number of tourists arriving in the country is not enough, since the country occupies only the third 
place in terms of the total profit gained from international tourism. In addition, this strategy focuses on increasing competition in the tourism sector and importance of this direction, since, according to the experts, by 2030 the number of tourists will have doubled and reached 2 billion people. As a result, the authors of the strategy set France the task of attracting at least $5 \%$ of the new flow of tourists, as well as creating 500,000 jobs in the tourism sector by 2030 .

The goal in view is planned to be achieved thanks to thirty formulated solutions, combined in five areas:

1) Improvement of the quality and diversity of tourist offers in France;

2) Development of transport infrastructure connecting airports, stations and the historical center of the cities;

3) Introduction of information technology in the field of international tourism;

4) Improvement of the quality of vocational education in the field of tourism;

5) Improvement of the availability of tourism in France.

Considering this strategy, it is important to note that the suggested solutions differ in a specific approach to the problem and in a high degree of elaboration. They comprehend the indications of individual infrastructure objects that need to be improved, and provide the references to specific programs. This document is also of great importance in the context of the foreign cultural policy of France, as it emphasizes the utmost significance of the tourism sector as a source for "cultural radiation" of France in other countries.

Clearer tasks for international tourism are formulated in another document of the French Ministry of Foreign Affairs, adopted in 2015, "Five advanced directions to update the tourist image of France." It represents a specific program for promoting the French tourism brand abroad and developing its new lines: wine tourism, craft tourism, ecotourism, summer mountain tourism, "night tourism" (tourism with visits to theaters, concerts, clubs in the evening). This strategy enables to present an updated image of France abroad, to draw attention to the new strengths of the country's cultural image, which can increase the interest of foreign tourists. The items concerning the regulation of tourism are presented in documents developed by other French international tourism operators. So, it is worth paying attention to the French Council for the Promotion of Tourism (Le Conseil de promotion du tourisme), which has elaborated the strategy "Six measures to enhance the role of French tourism." The time frame is the years 2014-2020. The necessary actions for the development of international tourism proposed by the Council fall into six categories: gastronomy and winemaking; travel brands; digital technology; hotel business and business tourism; Media and public relations, education. The development of these areas within the framework of international tourism furthers the improvement of the image of France, and also strengthens the interest in it abroad, which intersects with the tasks of the French foreign cultural policy.

The Made in Paris program contains measures to restore the confidence of foreign tourists in the Ile-de-France region and to promote the positive image of Paris as a city of art, fashion, gastronomy. It was launched in the spring of 2016. This program is targeted primarily at those countries from where most tourists come to France. So, the program mentions the United Kingdom, Spain, Canada, the USA, Japan, China, India and Russia. The intended measures included disseminating the advertisements demonstrating the positive image of Paris on social networks, airports and airplanes; hosting thematic events with the involvement of foreign journalists, organizing joint projects with partner cities of Paris, in particular, with New York and Tokyo, creating a feature film dedicated to Paris.

The Tourisme sûr program embraces all French regions. It was designed in order to convince foreign tourists of the safety of France as a tourist destination. This plan contains two important components: internal technical measures to enhance security in French cities and measures to improve the perception of the country's image abroad. In particular, the actions of tourism offices located abroad and the French diplomatic agencies to disseminate information on security measures taken are mentioned as the essential steps for foreign cultural policy.

\section{Summary}

For favorable development of the tourism sector and subsequent positive impact on the socio-economic situation of France in the country there are a number of state institutions. The following are distinguished: Ministry of Foreign Affairs and International Development; Ministry of Commerce and Finance; Interagency Committee on Tourism, Tourism Promotion Council, Atout France, etc. Within the framework of their activities, the programs aimed at developing tourism in the country and increasing brand awareness of the country beyond its borders have been developed and implemented. In particular, this article considers the strategies of the French Ministry of Foreign Affairs ("30 specific solutions for French international tourism as a world leader" and "Five advanced directions to update the tourist image of France"), as well as the programs "Made in Paris" and "Tourisme sûr". 
These events were created both to develop the mechanisms for the functioning of the sphere within the country, and to increase keenness on France from foreign tourists.

\section{5. conclusions}

Thus, the tourism sector in France makes a very significant contribution to the enrichment and financial well-being of the state. That is why, for its maintenance and normal functioning at the appropriate level, government institutions and other organizations of state importance develop various kinds of measures aimed at raising the country's status among other states and thereby attracting reinvestments in the French state treasury. In this article we have taken a look at the main institutional units of the French Republic in the field of tourism and presented the principal directions of their activities in the home country and abroad.

\section{Acknowledgements}

The work is performed according to the Russian Government Program of Competitive Growth of Kazan Federal University.

\section{References}

7 reasons to go to France in 2019. Retrieved from https://ru.france.fr/liste/7-prichin-poehat-vo-franciu-v-2019-godu

Atout France. Chiffres clés et études. Retrieved from http://atout-france.fr/services/chiffres-cles-et-etudes

Conseil national du tourisme. Histoire, organisation, publications. Retrieved from http://www.entreprises.gouv.fr/files/files/directions_services/tourisme/acteurs/cnt/livret-CNT.pdf

France Tourism Development Agency Website (Atout France). Retrieved from https:// www.atorus.ru/mission

Le site du Gouvernement français. La stratégie pour un tourisme français leader mondial. Retrieved from http://www.gouvernement.fr/action/la-strategie-pour-un-tourisme-francais-leader-mondial

Ministère des Affaires étrangères et du Développement international. 30 décisions très concrètes pour un tourisme français leader mondial. Retrieved from http://www.diplomatie.gouv.fr/fr/politique-etrangere-de-la-france/tourisme/l-action-du-maedi-en-matiere-de -promotion-du-tourisme/30-decisions-tres-concretes-pour-un-tourisme-francais-leader-mondial/

Novichkov, V. I., \& Polozkov, M. Yu. (2008). Analysis of the Experience of State Regulation of Tourism in Developed Countries. Proceedings of the Ural State Economic University, 3(22). Retrieved from

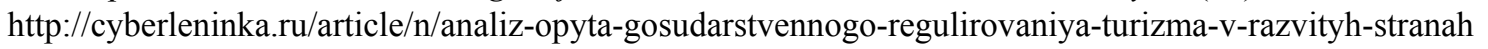

Politique étrangère de la France. Tourisme en chiffres. Retrieved from http://www.diplomatie.gouv.fr/en/french-foreign-policy/tourism

Tourism as an Important Sector of the French Economy. Retrieved from https://ru.france.fr/article

World Data Atlas (France). Retrieved from http://www.google.com/amp/knoema.ru/atlas

\section{Copyrights}

Copyright for this article is retained by the author(s), with first publication rights granted to the journal.

This is an open-access article distributed under the terms and conditions of the Creative Commons Attribution license (http://creativecommons.org/licenses/by/4.0/). 